\title{
TP53 NM_000546.5:c.843_844delCCinsTT
}

National Cancer Institute

\section{Source}

National Cancer Institute. TP53 NM 000546.5:C.843 844delCCinsTT. NCI Thesaurus. Code C146922.

A complex substitution where the nucleotide sequence at positions 843 and 844 of the coding sequence of the TP53 gene has changed from cytosine-cytosine to thyminethymine. 